\title{
Assessing discharge periodicity in mountain catchments using classified environmental conditions (Tatra Mountains, Poland)
}

\author{
BOROWSKA-PAKUŁA Joanna (Dhttps://orcid.org/oooo-00o3-2072-o809; e-mail: jb.pakula@gmail.com

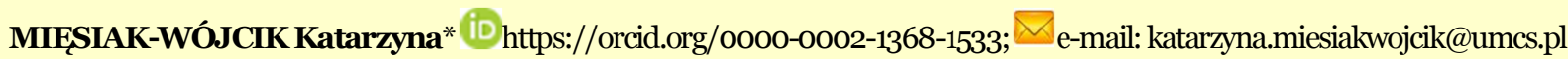 \\ ${ }^{*}$ Corresponding author \\ Department of Hydrology and Climatology, Institute of Earth and Envronmental Science, Maria Curie-Sklodowska \\ University, Aleja Kraśnicka 2D, 20-O31 Lublin, Poland
}

Citation: Borowska-Pakuła, J, Mięsiak-Wójcik K (2022) Assessing discharge periodicity in mountain catchments using classified environmental conditions (Tatra Mountains, Poland). Journal of Mountain Science 19(1). https://doi.org/10.1007/s11629-021-6736-0

(C) Author(s) 2022

\begin{abstract}
The periodicity of a river expressed in cycles of various lengths (monthly, seasonal, multiannual) is a result of climatic factors and overlapping environmental conditions within its catchment. In uncontrolled or poorly surveyed catchments, it is very difficult to determine the duration of a stream's hydrological activity. This is especially relevant for catchments with complicated water circulation in karstic rocks. The present study concerns the small catchment of the Strążyski Potok river located in the area of the Tatra National Park, in the Western Tatras. The observation period covered the 2015 hydrological year, which differed hydrologically from average conditions. This study aims to develop a simple method to explain the processes shaping the mountain stream discharge periodicity. The research employed periodic field observations linked with climatic and non-climatic factors. Environmental conditions were assessed as four classes reflecting their influence on appearance or disappearance of mountain stream water. Class boundaries were the values of quartiles. The degree of correspondence between environmental factors and stream field observations was described via the Index DC (Degree Correspondence Index) approach. Complete correspondence (Index DC $=0$ ) was found
\end{abstract}

Received: $11-$ Feb-2021

1 $^{\text {st }}$ Revision: 09-Jun-2021

$2^{\text {nd }}$ Revision: 03-Sep-2021

Accepted: $19-\mathrm{Nov}-2021$ in $23 \%$ catchments, a weak relationship between conditions favouring discharge and actual condition (Index $\mathrm{DC}=-1,+1$ ) was noted within 11 catchments, while in 9 catchments, no such relationship was found (Index DC $=-2,+2$ ). The obtained results indicate a correspondence or lack thereof between the environmental potential of the catchment and its discharge periodicity. The discrepancies between the assessment of the influence of climatic and nonclimatic factors and the data collected during field observations provide a basis for more detailed studies. Continuation of these studies based on the proposed classifications will allow for a more complete explanation of water disappearance in river channels and the determination of their short- and long-term discharge periodicity.

Keywords: Discharge periodicity; Small mountain catchment; Tatra Mountains; Environmental analysis

\section{Introduction}

The discharge periodicity of rivers is affected by a number of factors. The most important include climatic factors, geological (among others, infiltration properties of rocks) and tectonic conditions, overlapping primary features of land relief and human activity. Studies to date evidence that more 
than $30 \%$ of the total length of rivers on earth may be intermittent (Datry et al. 2014). Because many streams are not subject to continuous monitoring, in reality, this value may even exceed 50\%. In many regions, meteorological droughts recorded in recent years have brought about a change in the character of streams from perennial - to intermittent, or even episodic (Spinoni et al. 2015; Dorney and Russell 2018; Sauquet et al. 2020; Shanafield et al. 2021). This particularly concerns areas of the Temperate Zone that are have been formerly subject to melioration works and high withdrawal of groundwaters and surface waters for economic purposes, as well as areas that have experienced transformations of spatial management.

In addition to areas intensively used by man, changes in the discharge periodicity of rivers are also evident in mountain catchments. The observed phenomenon is confirmed by numerous studies, analysing, among others, the dynamics of occurrence of low flows or the effect of different processes and phenomena on transformations of the hydrological regime (Holko et al. 2009; Peña-Gallardo et al. 2019). Analyses (particularly those concerning the precipitation-runoff dependency) employ both simulation (Peters et al. 2003; Pociask-Karteczka et al. 2010; Karabová et al. 2012; Madzia et al. 2013; Górnik et al. 2017; Jensen et al. 2018) and experimental methods in the scope of field research (Penna et al. 2014). It should be remembered, however, that the discharge periodicity of rivers is not a constant element - it changes in an annual and multi-annual cycle (Li et al. 2014; Rutkowska et al. 2018).

Small mountain catchments are a model area of research for explaining the processes that bring about changes in water circulation (Colson et al. 2008; Broxton et al. 2009; Robredo Sánchez et al. 2012; Ragettli et al. 2017; Latron and Lana-Renault 2018; Zuecco et al. 2018; Guastini et al. 2019; Costache et al. 2020). In mountainous areas, the high climatic factor dynamics induce quick reactions within water courses that is expressed by flash floods, deep low flows, and often complete drying up of stream beds. Indeed, lack of stability and continuity of flow in streams (discharge periodicity) is a phenomena commonly occurring in mountainous regions, particularly in karst areas. Knowledge of the factors causing discharge periodicity, as well as the environmental elements influencing it, is important for recognizing the dynamics of water resources in source areas that give rise to rivers forming major river systems (Sando and Blasch 2015; Villines et al. 2015; Costigan et al. 2016; Robinson et al. 2016; Martin et al. 2021). Frequent disappearances of water in riverbeds also disrupt river continuity. Widely available sources of information on this phenomenon are topographic or thematic maps, e.g., hydrographic and hydrogeological maps and/or the results of direct field observations (Chorley and Dale 1972; Fritz et al. 2013; Williamson et al. 2015; Paillex et al. 2020). However, the streams marked on the maps document only the averaged state or observations from the mapping period, and in reality, the discharge periodicity is a result of overlapping climatic factors and catchment environmental conditions. In addition to anthropogenic factors, climatic factors are therefore most likely to determine the change in periodicity of streams. Hence, the representation of this situation on maps issued in different periods differs. In addition, it lacks information on the nature of discharge periodicity.

The objective of this paper is the determination of the discharge periodicity of a mountain river system through the assessment of the effect of selected non-climatic (infiltration properties of rocks, land slope, forest cover) and climatic environmental factors (precipitation, temperature) on shaping runoff from the catchment. As a research area, the small mountain catchment of the Strażyski Potok river was selected. This is characterised by a negligible impact of anthropogenic factors (it is within a long established national park). It could be therefore assumed that all conclusions result only from the relationship between flow instability and natural factors.

\section{Study Area}

The catchment of the Strążyski Potok (SP), occupying 502.5 ha, is located in southern Poland in the range of the Tatra Mountains (Carpathians Mountains) (Fig. 1), within the boundaries of the Tatra Mountains National Park. The fluvial system of the catchment comprises the main river SP, its largest tributary (in catchment no. 9), and several tens of nameless tributaries that were assigned topographic names and numbers (Table 1). The hydrographic relations in the study area were presented for the first 


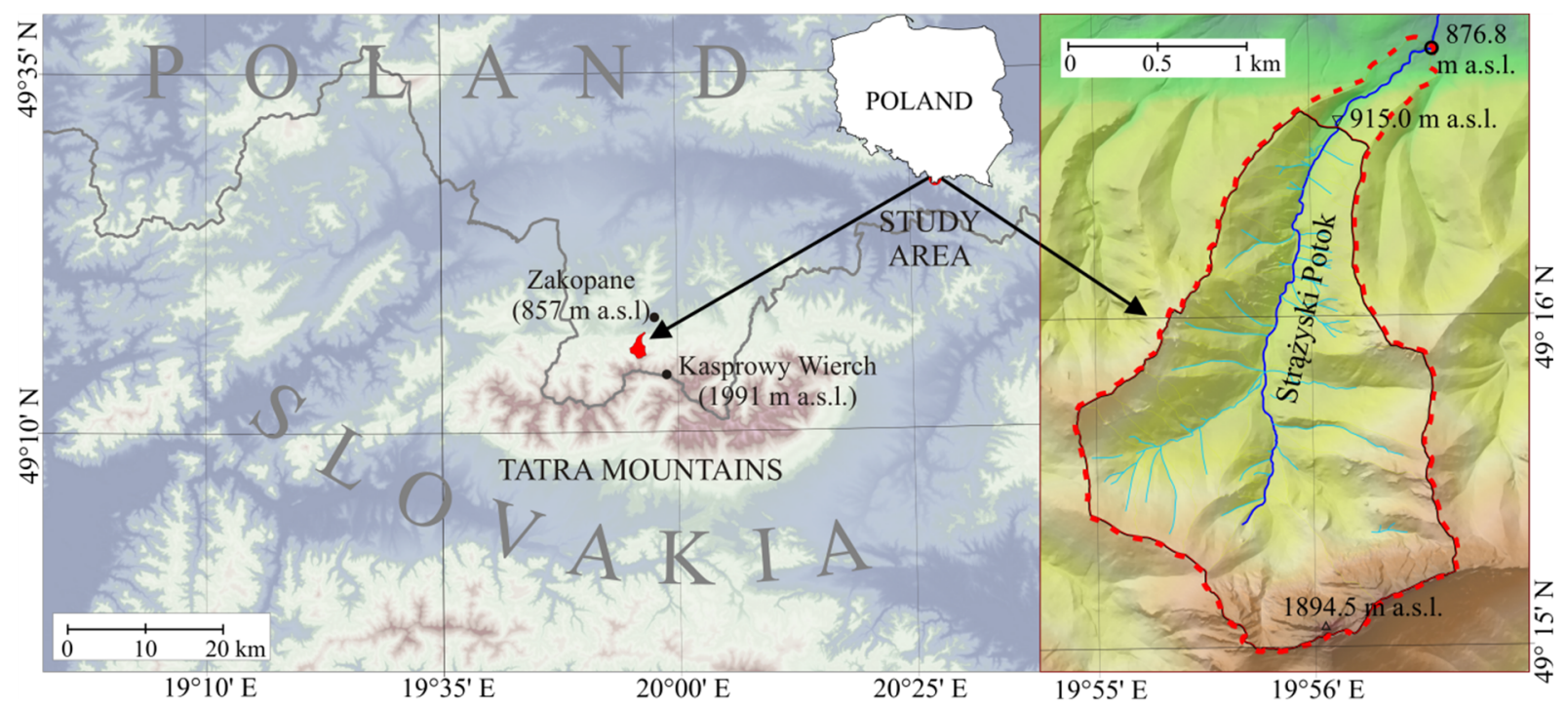

Fig. 1 Location of the Strążyski Potok catchment area.

Table 1 Basic morphometric data on elementary catchments in the Strążyski Potok (SP) basin.

\begin{tabular}{|c|c|c|c|c|c|c|}
\hline $\begin{array}{l}\text { No. of } \\
\text { catchment }\end{array}$ & $\begin{array}{l}\text { Real area } 3 \mathrm{D} \\
\text { (ha) }\end{array}$ & $\begin{array}{l}\text { Length of water } \\
\text { divide }(\mathrm{km})\end{array}$ & $\begin{array}{l}\text { Max height } \\
\text { (m a.s.l.) }\end{array}$ & $\begin{array}{l}\text { Min height } \\
\text { (m a.s.l.) }\end{array}$ & $\begin{array}{l}\text { Average height } \\
\text { (m a.s.l.) }\end{array}$ & $\begin{array}{l}\text { Average } \\
\text { direction }\left({ }^{\circ}\right)\end{array}$ \\
\hline$A^{*}$ & 502.5 & 9.9 & 1894.5 & 876.8 & 1232.2 & $\mathrm{~N}\left(5^{\circ}\right)$ \\
\hline $\mathrm{B}^{* * *}$ & 482.2 & 8.7 & 1894.5 & 915.0 & 1247.9 & $\mathrm{~N}\left(3^{\circ}\right)$ \\
\hline 1 & 3.3 & 0.9 & 1445.9 & 1160.0 & 1286.3 & $\operatorname{NE}\left(26^{\circ}\right)$ \\
\hline 2 & 79.9 & 3.0 & 1894.5 & 1160.0 & 1513.3 & $N\left(346^{\circ}\right)$ \\
\hline 3 & 11.8 & 1.4 & 1507.4 & 1159.6 & 1353.7 & $\mathrm{NE}\left(48^{\circ}\right)$ \\
\hline 4 & 0.6 & 0.3 & 1211.0 & 1116.4 & 1162.7 & $\operatorname{NE}\left(62^{\circ}\right)$ \\
\hline 5 & 4.1 & 0.9 & 1323.1 & 1088.8 & 1219.1 & $\operatorname{NE}\left(56^{\circ}\right)$ \\
\hline 6 & 0.8 & 0.5 & 1227.6 & 1081.0 & 1149.5 & $\mathrm{E}\left(76^{\circ}\right)$ \\
\hline 7 & 84.8 & 3.1 & 1859.3 & 1075.0 & 1397.4 & $\mathrm{NW}\left(310^{\circ}\right)$ \\
\hline 8 & 17.7 & 2.0 & 1533.6 & 1055.0 & 1274.2 & $\mathrm{NW}\left(306^{\circ}\right)$ \\
\hline 9 & 83.9 & 3.5 & 1489.3 & 1020.0 & 1248.7 & $\operatorname{NE}\left(55^{\circ}\right)$ \\
\hline 10 & 40.8 & 2.6 & 1469.1 & 1020.0 & 1217.4 & $\mathrm{~W}\left(279^{\circ}\right)$ \\
\hline 11 & 11.5 & 1.6 & 1376.4 & 1020.0 & 1203.8 & $\mathrm{E}\left(101^{\circ}\right)$ \\
\hline 12 & 11.4 & 1.5 & 1353.2 & 995.0 & 1176.5 & $\mathrm{E}\left(95^{\circ}\right)$ \\
\hline 13 & 8.1 & 1.2 & 1272.8 & 985.0 & 1137.8 & $\operatorname{SE}\left(114^{\circ}\right)$ \\
\hline 14 & 11.2 & 1.6 & 1376.3 & 975.0 & 1174.7 & $\operatorname{NW}\left(299^{\circ}\right)$ \\
\hline 15 & $5 \cdot 5$ & 1.1 & 1291.4 & 971.0 & 1107.9 & $\mathrm{~W}\left(277^{\circ}\right)$ \\
\hline 16 & 4.7 & 1.1 & 1279.6 & 970.0 & 1109.9 & $\mathrm{~W}\left(286^{\circ}\right)$ \\
\hline 17 & 2.3 & 0.6 & 1155.1 & 960.8 & 1072.1 & $\mathrm{E}\left(94^{\circ}\right)$ \\
\hline 18 & $3 \cdot 3$ & 0.8 & 1183.3 & 955.0 & 1084.1 & $\mathrm{~W}\left(288^{\circ}\right)$ \\
\hline 19 & 2.0 & 0.7 & 1151.3 & 955.0 & 1071.0 & $\mathrm{~W}\left(283^{\circ}\right)$ \\
\hline 20 & 3.7 & 0.8 & 1144.7 & 950.0 & 1065.0 & $\mathrm{~W}\left(282^{\circ}\right)$ \\
\hline 21 & 10.9 & 1.5 & 1207.5 & 945.0 & 1116.5 & $\mathrm{E}\left(83^{\circ}\right)$ \\
\hline 22 & 6.3 & 1.1 & 1188.5 & 935.0 & 1080.3 & $\mathrm{E}\left(85^{\circ}\right)$ \\
\hline 23 & 2.3 & 0.7 & 1091.4 & 930.0 & 1030.7 & $\operatorname{NW}\left(304^{\circ}\right)$ \\
\hline 24 & 5.1 & 1.1 & 1153.2 & 928.4 & 1038.3 & $\mathrm{E}\left(85^{\circ}\right)$ \\
\hline 25 & 3.1 & 0.8 & 1077.5 & 927.4 & 1009.8 & $\mathrm{NW}\left(325^{\circ}\right)$ \\
\hline 26 & 3.8 & 0.9 & 1063.8 & 922.8 & 985.7 & $\mathrm{E}\left(96^{\circ}\right)$ \\
\hline
\end{tabular}

Note: $A^{*}$ - total catchment of SP; $B^{* *}$ - SP catchment until the water gauge.

time in the scope of preparation of the Hydrographic Map of West Tatra Mountains (Wit and Ziemońska 1960). In later years, hydrological researches in the SP catchment were conducted by Łajczak (1996), Żelazny (2012), Żelazny et al. (2013) and Ballesteros-
Cánovas et al. (2015).

The primary factors that determined the development of the V-shaped Strążyska Valley were the activity of flowing and precipitated waters, and gravitational mass movements (Klimaszewski 1988). 
The highest point in the catchment is Giewont Summit $(1,894 \mathrm{~m}$ a.s.l.), and the lowest is the intersection of SP with the stream from ku Dziurze Valley (877 $\mathrm{m}$ a.s.l.). The system of geological formations in the catchment has latitudinal orientation. The SP catchment is built mainly of Mezozoic limestones and dolomites. The most favourable filtration conditions, determined based on measurements of fissuring of a rock massif, occur within the High-Tatric series (nappe) of Giewont (Barczyk et al. 1995; Barczyk et al. 2002). Averaged values of the filtration coefficient $(k)$ for the lithological-stratigraphic complex was evaluated for $3.810^{-2} \mathrm{~m} \cdot \mathrm{s}^{-1}$. In some of its fragments, however, subsurface flow is considerably faster, because the aforementioned value does not consider karst cavities. In contrast to highly permeable rocks of the HighTatric series, a narrow zone of easily weathering, impermeable or weakly permeable Cretaceous marls and glauconitic limestones occurs at the northern foot of Giewont (filtration coefficient was specified at a level of $k=2.7 \cdot 10^{-5} \mathrm{~m} \cdot \mathrm{s}^{-1}$ ). The marl zone constitutes a border area between the High-Tatric zone in the south, and the Subtatric zone occupying the middle and northern part of the SP catchment. The lower Subtatric series is characterised by moderate filtration conditions (average value $k=2.210^{-3} \mathrm{~m} \cdot \mathrm{s}^{-1}$ ) (Barczyk et al. 1995; Barczyk et. al. 2002). The variability of permeability of rocks building the catchment determines the development of the river network in the form of streams with a varied discharge periodicity (see Section 4.2).

SP catchment shows high spatial variability of climatic conditions, and very high variability of weather types (Niedźwiedź et al. 2015). Annual precipitation totals increase from the forefield of the Tatra Mountains $(1133 \mathrm{~mm})$ towards higher parts of the mountains, where it reaches $1800 \mathrm{~mm}$. The maximum monthly values of precipitation usually occur in June and July, and minimum in January and February (Woźniak 2013). The air temperature gradient in the vertical profile is also characteristic. Mean annual air temperature values at the foot of the mountains are $5.7^{\circ} \mathrm{C}$, and in the highest parts: $-0.4^{\circ} \mathrm{C}$ (Kasprowy Wierch). Therefore, boundaries between climatic-vegetation zones are evident: for instance, the altitudinal boundary where temperate forests give way to dwarf pines (Hess 1996). In terms of land cover, coniferous forests occupy the largest areas approximately $68 \%$ (primarily spruce). Solely in the northern parts of the SP catchment, the valley slopes are also overgrown by deciduous forests (approximately 10\%, primarily beech). The highest, southern parts of the catchment are covered with exposed rocks with screes and rocky rubbles (approximately $17 \%$ of total study area), and locally also with grassy vegetation and dwarf pine.

The SP catchment belongs to the basin of the Biały Dunajec River, which is an element of the river system of the longest river in Poland - the Vistula. The central part of the area is occupied by Strązyska Valley, with SP running through its floor in a straight line (Fig. 2). SP starts its course from springs under
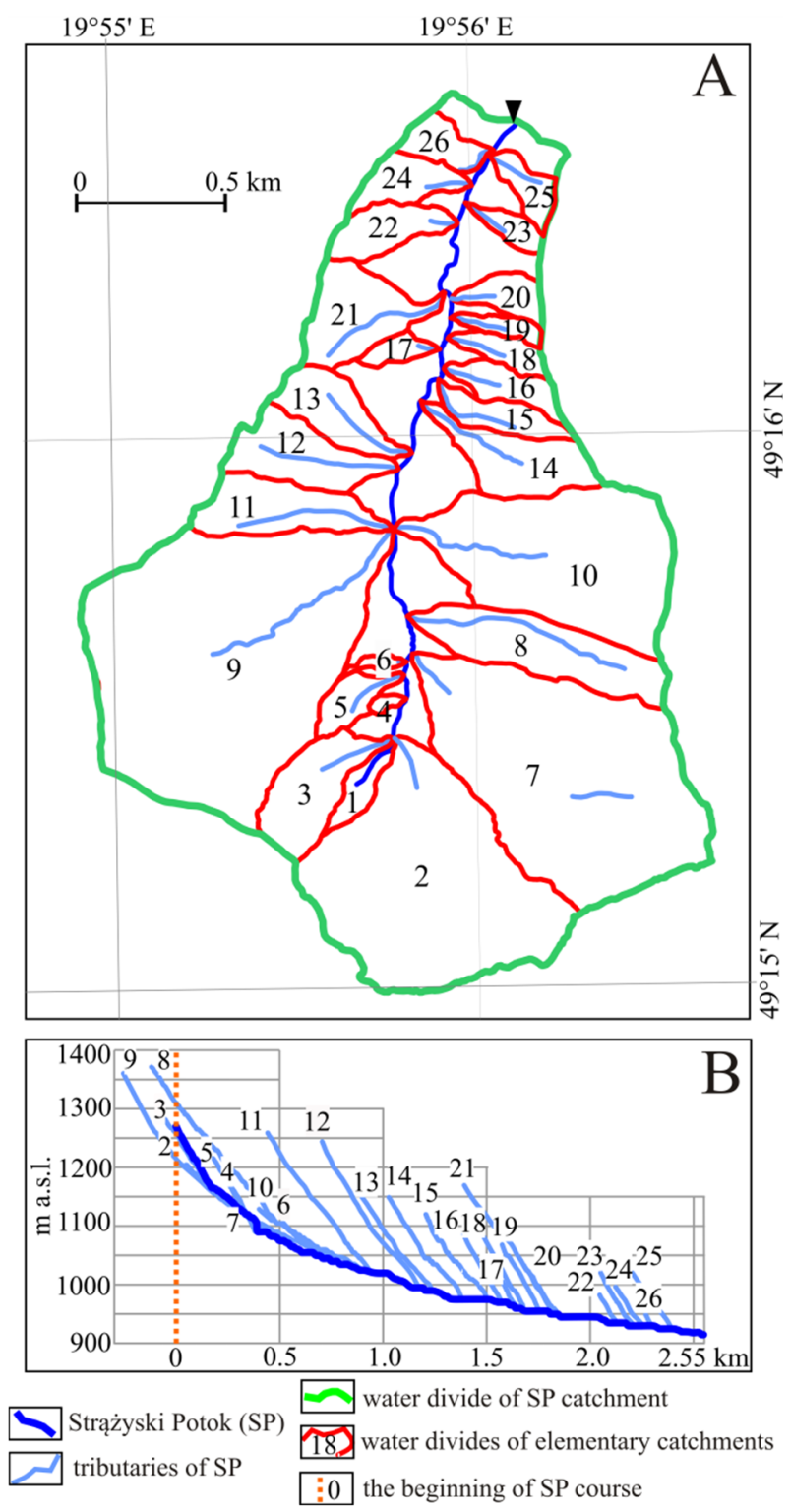

Fig. 2 The Strążyski Potok catchment with division into elementary catchments (A) and longitudinal stream profiles (B). 
the Giewont Summit at a height of $1270 \mathrm{~m}$ a.s.l. The longest stream is the main river - SP $(3.3 \mathrm{~km})$, and among its tributaries - Potok Grzybowiecki (stream No. 9) $(1.2 \mathrm{~km})$. Lengths of the remaining tributaries, with a perennial, intermittent (regularly transporting water in the humid season), and episodic character (sporadically or irregularly transporting water over short periods of time) do not exceed $1 \mathrm{~km}$. As a perennial stream, SP has a length of $2.2 \mathrm{~km}$ until the water gauge in Młyniska (915 m a.s.l.; N 49 ${ }^{\circ} 16^{\prime} 34.61^{\prime \prime}$, E $\left.19^{\circ} 56^{\prime} 08.00 "\right)$ that closes the analysed catchment. The SP system transports the catchment waters northwards (Fig. 2). From the eastern and western parts of the river basin, 13 streams flow into it. Some adopt the direction of tectonic faults.

The analysis of historical cartographic materials covering the SP catchment showed that at the turn of the 20th and 21st centuries, the greatest number of streams (70) was presented on the 1995 map, and the least (37) on the 1934 Photogrammetric Map of the Tatra National Park. The highest number of perennial (46) and intermittent (24) streams is shown on the 1995 Topographic Map of the Polish Tatra Mountains. This study also documents the largest total length of perennial streams $(8.74 \mathrm{~km})$. In contrast, the total length of the intermittent streams $(10.25 \mathrm{~km})$ is shown on the map prepared during the hydrological mapping of the SP catchment carried out in the 1950 S (Wit and Ziemońska 1960). However, the indicated cartographic materials are characterized by a different degree of measurement detail, and the studies on which they were based document a one-time and short-term situation. The discrepancy in information contained in cartographic documents became a stimulus to undertake research on the discharge periodicity of mountain streams. The analyses conducted in this study combine assessment of the catchment environment with repeated field observations conducted in different seasons of the hydrological year.

Characteristic features of streams in the Tatra Mountains include frequent slumps of slopes resulting from the variability of resistance of rocks to water erosion, and which evidence the young age of the land relief (Fig. 2-B). The streambed average slope of SP is $4.8^{\circ}$, while average inclinations of its tributary channels exceed $15^{\circ}$, reaching a maximum of $31^{\circ}$ (No. 11).

For the purposes of detailed hydrological analyses, 26 elementary topographic catchments of the main tributaries and the direct catchment of SP were designated in the analysed catchment (ending with the water gauge) (Fig. 2, Table 1). The largest elementary catchments are located in the upper part of the SP catchment.

\section{Material and Methods}

Collection of research material in 2015 involved a preliminary desk study and field research. All available cartographic documents covering the catchment area were calibrated by means of GIS tools. The resulting material was used in field research. In hydrological year 2015, 11 sets of field observations were performed that documented water flow in the channel of the main stream and in the mouth sections of its tributaries. SP discharge in profile Młyniska was obtained from the data of the Institute of Meteorology and Water Management - National Research Institute (IMWM). Observations from a given day were correlated with the meteorological situation of the two-week period preceding field research.

Meteorological characteristics were based on precipitation and temperature data from two stations of IMWM - Zakopane (857 m a.s.l.) and Kasprowy Wierch (1,991 $\mathrm{m}$ a.s.l.). For elementary catchments, values of these climatic components were calculated using the hypsometric method, taking into account their value from the mean elevation of the catchment above sea level.

Information concerning selected non-climatic environmental parameters (infiltration properties of rocks, land slope, and forest cover) of the analysed catchment was obtained from data bases published on websites of the Head Office of Geodesy and Cartography (mapy.geoportal.gov.pl) and National Geological Institute - Detailed Geological Map of the Tatra Mountains 1:10 ooo (cbdgportal.pgi.gov.pl/ smgt/). The selection of non-climatic environmental elements was dictated by data availability and their detail.

The assessment of discharge periodicity of rivers in the mountain catchment involved the development of a simple system based on the classification of selected environmental parameters (Fig. 3). Since the application of mathematical functions in such an assessment is very complicated or impossible, one of the methods of ordinal statistics was applied - the method of separating the values of data sets into 


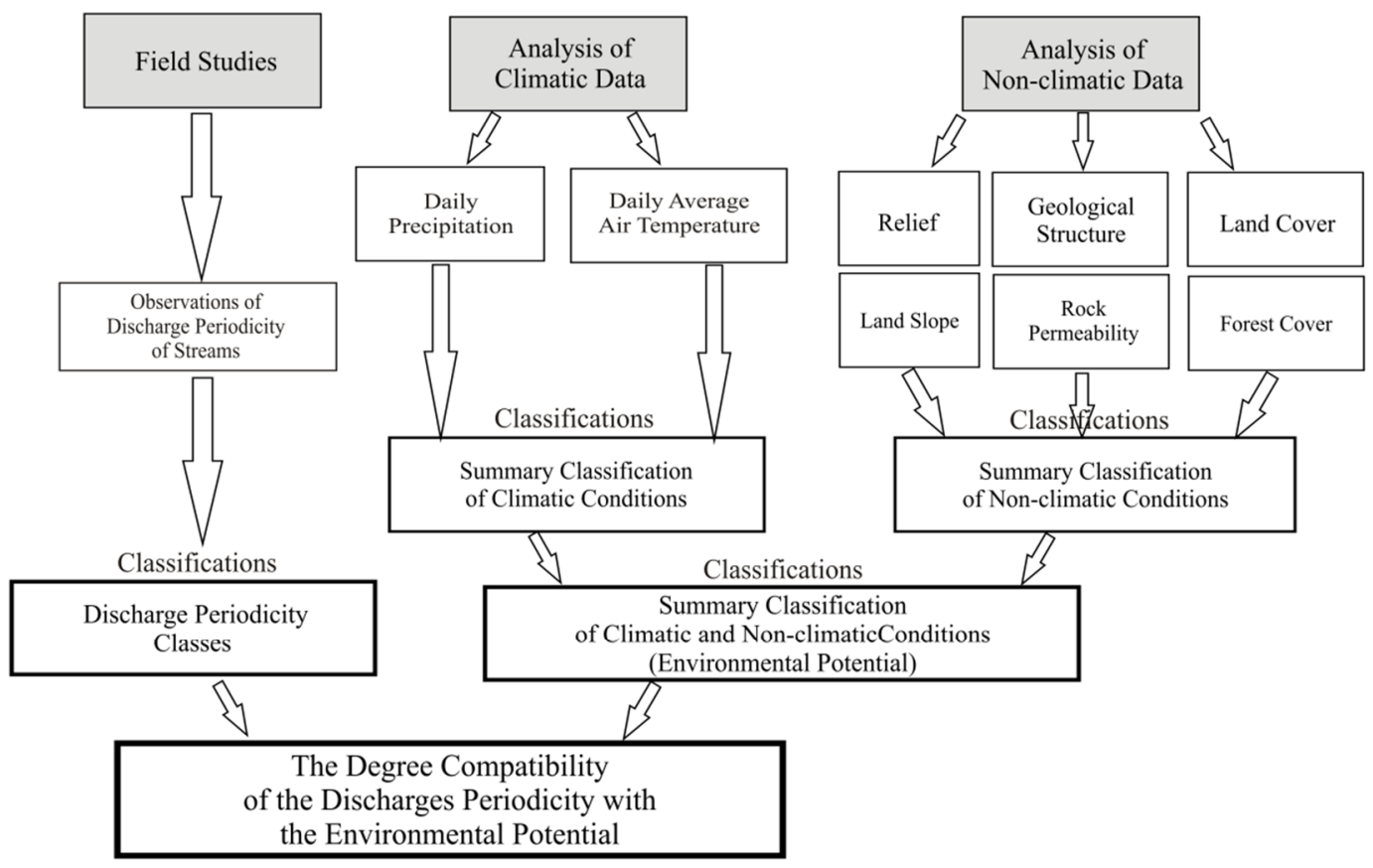

Fig. 3 Scheme of the proposed evaluation system of discharge periodicity in mountain catchments using selected classified environmental conditions.

intervals determined by quartiles (Tukey 1977; Langford 2006). In this way, individual non-climatic and climatic features of the catchment environment were assessed as four classes, from those playing the smallest role in discharge periodicity (class 1), to those that should guarantee continuous outflow (class 4). The intervals between the lower quartile $\left(Q_{1}\right)$ and the median (Q2) encompass conditions that are "moderately unfavourable" and that between the median (Q2) and the upper quartile (Q3) are "moderately favourable" for discharge stability (Fig 4).

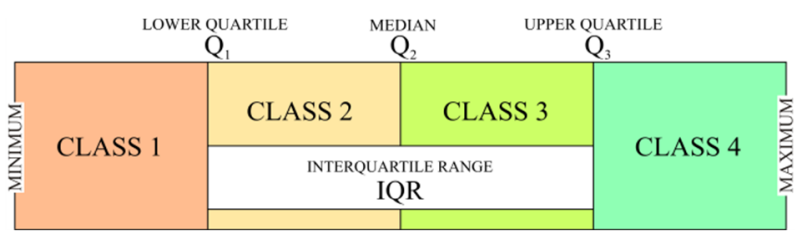

Fig. 4 Classification scheme of values of climatic and non-climatic conditions according to quartiles.

The individual elements of the classified environment were separately grouped into two larger sets, and the classification was repeated with designation into climatic and non-climatic elements summed up. At the next stage of analysis, these classes were combined with each other. In this way, the final classification of environmental conditions of individual catchments was obtained and compared with the results of field observations. This comparison made it possible to determine the degree of correspondence between the proposed classification and the actual discharge periodicity of the observed streams.

The analyses of climatic factors employed mean values from two-week periods preceding field observations of the rivers. The classification was performed for two periods of the hydrological year: for the winter (Nov-Apr) and summer half-year (MayOct) according to Polish conditions (Table 2).

In accordance with the assessment of permeability of rocks building the northern slope of the Tatra Mts. (Barczyk et al. 1995), four permeability classes were determined for the examined area (Table 3). Rocks with very high permeability were classified into 1st class $\left(k>10^{-3} \mathrm{~m} \cdot \mathrm{s}^{-1}\right)$, moderate permeability into $2^{\text {nd }}$ class $\left(k<10^{-3} \geq 10^{-5} \mathrm{~m} \cdot \mathrm{s}^{-1}\right)$, low permeability into $3^{\text {rd }}$ class $\left(k<10^{-5} \geq 10^{-7} \mathrm{~m} \cdot \mathrm{s}^{-1}\right)$ and semi-permeable permeability $\left(k<10^{-7} \mathrm{~m} \cdot \mathrm{s}^{-1}\right)$ into $4^{\text {th }}$ class. The permeability conditions of each elementary catchment were determined using the index $I_{p}$ (Eq. 1):

$$
I_{p}=\Sigma(\mathrm{A} 1 \times 1)+(\mathrm{A} 2 \times 2)+(\mathrm{A} 3 \times 3)+(\mathrm{A} 4 \times 4)
$$

where: $I_{p}$ - index of average catchment permeability (non-dimensional); A (1-4) - contribution of surface area of rocks from particular classes in the elementary catchment (1-4); 1-4 - class number (which is also the class weight).

Due to high inclinations of slopes, a considerable 
Table 2 Classification of thermal and precipitation conditions

\begin{tabular}{l|l|l|l|l|} 
Climatic factors & \multicolumn{4}{|c}{ Class } \\
\cline { 2 - 6 } & 1 & 2 & 3 & 4 \\
\hline Temperature in winter half-year (Nov-Apr) $\left({ }^{\circ} \mathrm{C}\right)$ & $-8.31--5.00$ & $-4.99--2.39$ & $-2.38--1.32$ & $-1.31-3.99$ \\
\hline Temperature in summer half-year (May-Oct) $\left({ }^{\circ} \mathrm{C}\right)$ & $14.24-17.15$ & $10.29-14.23$ & $7.78-10.30$ & $1.49-7.79$ \\
\hline Mean daily precipitation in the winter half-year $(\mathrm{mm})$ & $0.44-2.00$ & $2.01-2.57$ & $2.58-3.23$ & $3.24-5.64$ \\
\hline Mean daily precipitation in the summer half-year $(\mathrm{mm})$ & $1.26-3.63$ & $3.64-3.89$ & $3.90-4.58$ & $4.59-5.90$
\end{tabular}

Table 3 Classification of selected non-climatic conditions

\begin{tabular}{|c|c|c|c|c|}
\hline \multirow{2}{*}{ Characteristic } & \multicolumn{4}{|c|}{ Class } \\
\hline & 1 & 2 & 3 & 4 \\
\hline Land slope (degree of mean land slope) & $35.91^{\circ}-45.00^{\circ}$ & $33.07^{\circ}-35.90^{\circ}$ & $29.91^{\circ}-33.06^{\circ}$ & $23.50^{\circ}-29.90^{\circ}$ \\
\hline Rock permeability $\left(I_{p}\right.$ index $)$ & $3.32-3.88$ & $3.10-3 \cdot 31$ & $2.97-3.09$ & $1.41-2.96$ \\
\hline Forest cover (\%) & $15.00-73.99$ & $74.00-81.49$ & $81.50-99.99$ & 100 \\
\hline
\end{tabular}

part of precipitation in mountainous areas reaches streambeds in the form of surface and sub-surface (hypodermic runoff, soil runoff) discharge. Catchments with the greatest slopes $>33.07^{\circ}$, characterised by rapid water runoff, were ascribed class 1 or 2, and catchments with smaller inclinations that favour river discharge periodicity, were designated classes 3 and 4 (Table 3 ).

Among types of land cover, forests and dwarf pine thickets play the most important role in maintaining proper retention of water resources in mountain areas (together described as forest retention). The areas slow down the rate of water runoff, and soils developed there show higher retention capacity than those on slopes with no forest cover (Zal et al. 2015). Four forest retention classes were also designated for the study area, corresponding to the percent share of surface area of forests and dwarf pine shrubs. The weakest class 1 was ascribed to catchments where forest cover is below $73.99 \%$, and the best class 4 was assigned to areas with $100 \%$ forest cover (Table 3 ).

\section{Results}

\subsection{Hydrometeorological situation in 2015 in the Strążyski Potok catchment}

The analysis of climatic components of the environment in the SP catchment in 2015 showed that the period of conducted observations was characterised by atypical distribution of meteorological-hydrological conditions in reference to the mean values for the area (Fig. 5). Precipitation of the winter half-year averaged from both stations (Nov-Apr) for years 1971-2015 was $531 \mathrm{~mm}$. In hydrological year 2015, precipitation of the winter half-year was lower than that from the multi-annual period by approximately $100 \mathrm{~mm}$, whereas evidently lower atmospheric precipitation was recorded in the upper part of the catchment. Reduction of atmospheric alimentation particularly occurred in the summer half-year (May-Oct) of 2015. Features characteristic of the precipitation distribution in the analysed catchment in the summer half-year 2015 include intensive precipitation in May, reaching $139 \%$ of the average value from the multi-annual period, and low atmospheric alimentation in other months, reaching only $21 \%$ of the monthly norm in August 2015. At the scale of the entire hydrological year 2015 , precipitation reached only $79 \%$ of the multi-annual norm.

A systematic decrease in precipitation was accompanied by a continuous increase in average monthly air temperature in the summer months (Fig. 5). In June - it was higher than the multi-annual average by $0.5^{\circ} \mathrm{C}$, and in August - by as much as $2.1^{\circ} \mathrm{C}$. Average air temperature for the entire catchment area for 2015 was $3 \cdot 3^{\circ} \mathrm{C}$. This was higher than the multiannual average by $0.7^{\circ} \mathrm{C}$.

Atypical distribution of precipitation and air temperature in 2015 brought about a change in the SP river regime. Maximum mean monthly discharges $\left(Q>0.20 \mathrm{~m}^{3} \cdot \mathrm{s}^{-1}\right)$ occurred in April and May, and not as usual in June and July (Fig. 5-A). High rainfall in May 2015 induced intensive melting of snow cover, and very low summer precipitation and lack of heavy downpours during the time resulted in a change in the cycle of runoff from the SP catchment (Fig. 5-B). Such a combination of meteorological conditions resulted in a decrease in discharge in SP to $90 \%$ of the multiannual norm in the winter half-year, to $72 \%$ in the summer half-year, and in the annual scale, to $78 \%$. 
A

\begin{tabular}{|c|c|c|c|c|c|c|c|c|c|}
\hline & \begin{tabular}{|c|}
$\mathrm{T}\left({ }^{\circ} \mathrm{C}\right)$ \\
$1971-2015$ \\
\end{tabular} & $\begin{array}{l}\mathrm{T}\left({ }^{\circ} \mathrm{C}\right) \\
2015 \\
\end{array}$ & \begin{tabular}{|c|}
$\mathrm{P}(\mathrm{mm})$ \\
$1971-2015$ \\
\end{tabular} & $\begin{array}{c}\mathrm{P}(\mathrm{mm}) \\
2015\end{array}$ & $\begin{array}{c}\mathrm{SC}(\mathrm{cm}) \\
1971-2015\end{array}$ & $\begin{array}{c}\mathrm{SC}(\mathrm{cm}) \\
2015 \\
\end{array}$ & $\begin{array}{c}Q\left(\mathrm{~m}^{3} \cdot \mathrm{s}^{-1}\right) \\
1971-2015\end{array}$ & $\begin{array}{c}Q\left(\mathrm{~m}^{3} \cdot \mathrm{s}^{-1}\right) \\
2015\end{array}$ \\
\hline \multirow{12}{*}{ 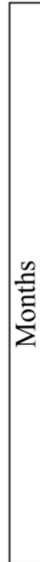 } & Nov & -1.1 & 0.8 & 91 & 26 & 41 & 12 & 0.09 & 0.06 \\
\hline & Dec & -4.5 & -4.1 & 88 & 50 & 63 & 28 & 0.08 & 0.04 \\
\hline & Jan & -5.6 & -5.6 & 85 & 126 & 80 & 70 & 0.08 & 0.06 \\
\hline & Feb & -5.5 & -4.8 & 72 & 64 & 98 & 108 & 0.07 & 0.04 \\
\hline & Mar & -2.9 & -2.5 & 89 & 88 & 106 & 110 & 0.10 & 0.10 \\
\hline & Apr & 1.5 & 1.0 & 107 & 86 & 96 & 120 & 0.14 & 0.20 \\
\hline & May & 6.6 & 6.8 & 156 & 217 & 55 & 63 & 0.14 & 0.23 \\
\hline & Jun & 9.5 & 10.0 & 189 & 113 & 11 & 0 & 0.22 & 0.12 \\
\hline & Jul & 11.4 & 12.6 & 202 & 88 & 1 & 0 & 0.23 & 0.06 \\
\hline & Aug & 11.3 & 13.4 & 156 & 32 & 1 & 0 & 0.17 & 0.04 \\
\hline & Sep & 7.4 & 7.7 & 127 & 173 & 8 & 1 & 0.13 & 0.13 \\
\hline & Oct & 3.6 & 4.1 & 93 & 89 & 18 & 17 & 0.11 & 0.13 \\
\hline & $\begin{array}{l}\text { nnual } \\
\text { in totals }\end{array}$ & 2.6 & 3.3 & 1455 & 1152 & 48 & 44 & 0.13 & 0.10 \\
\hline
\end{tabular}

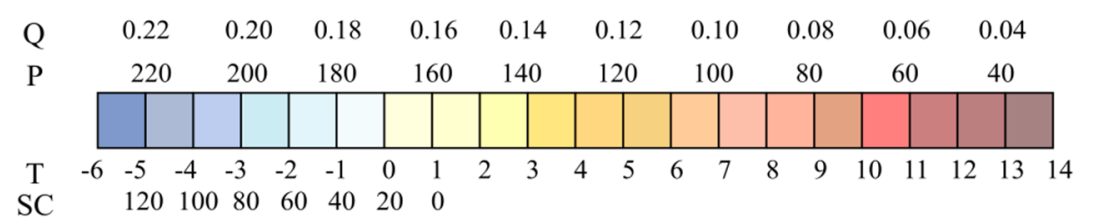

B

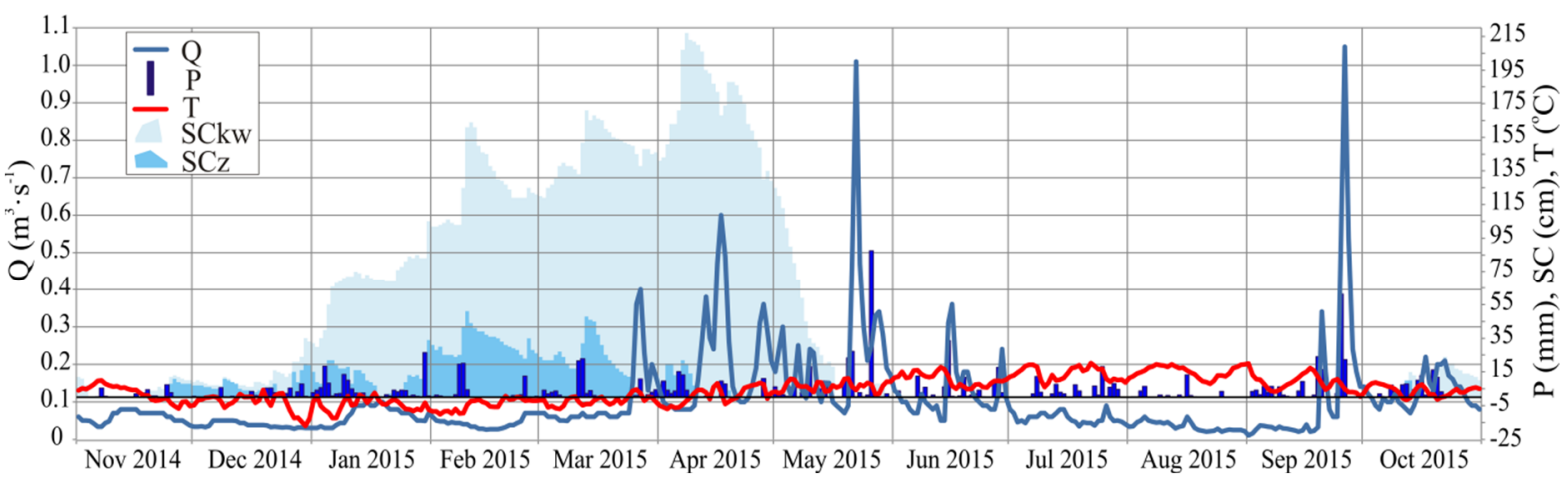

Fig. 5 Monthly, annual (A) and daily (B) hydrometeorological characteristics of the Strążyski Potok catchment in the multi-annual period 1971-2015 and in hydrological year 2015 (Q - average discharge, P - mean precipitation in Zakopane and Kasprowy Wierch Meteorological Stations, T - mean air temperature in Zakopane and Kasprowy Wierch Meteorological Stations, SC - maximum snow cover depth in Zakopane and Kasprowy Wierch Meteorological Stations, $\mathrm{SCz}$ - maximum snow cover depth in Zakopane Meteorological Station, SCkw - maximum snow cover depth in Kasprowy Wierch Meteorological Stations).

Discharge periodicity in SP in its middle and lower course was guaranteed by water resources of the snow cover, with a maximum thickness in the months at the turn of winter and spring (FebruaryMay) that was higher than the average from the multiannual period 1971-2015 (Fig. 5). The highest discharges in SP, exceeding $1 \mathrm{~m}^{3} \cdot \mathrm{S}^{-1}$ occurred when average air temperature oscillated around $5^{\circ} \mathrm{C}$. Low flows occurred in the winter period at temperatures lower than $-5^{\circ} \mathrm{C}$, and in summer at temperatures more than $15^{\circ} \mathrm{C}$. Evident reduction of flowing water resources (from 22 May to 1 September) was observed in the period of occurrence of average daily temperatures reaching up to $20^{\circ} \mathrm{C}$ (Fig. 5).

Field observations showed the lowest hydrological activity of the entire SP catchment in February and August 2015. In February, constant discharge was only recorded in the river draining catchment No. 26 and in the main river, and in the summer period, in August, in catchments No.: 1, 3, 9, 26 , and SP $\left(Q=0.03 \mathrm{~m}^{3} \cdot \mathrm{s}^{-1}\right)$. Almost the entire eastern part of the catchment was hydrologically passive in 
these periods. The greatest hydrological activity manifested in constant water discharge in rivers was observed in April in 10 and in October in 11 elementary catchments (Fig. 6).
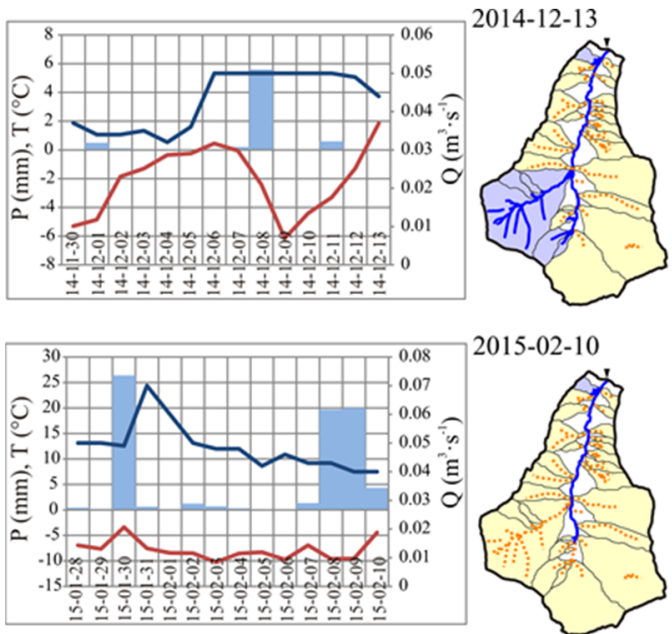

2015-02-10

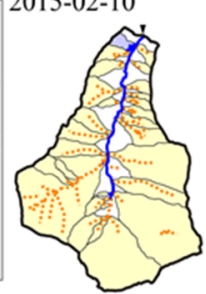

2015-04-19
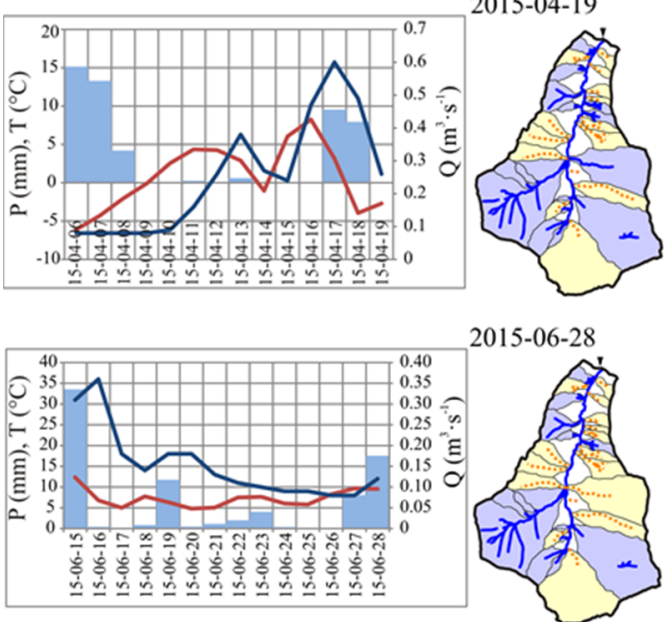

2015-08-27
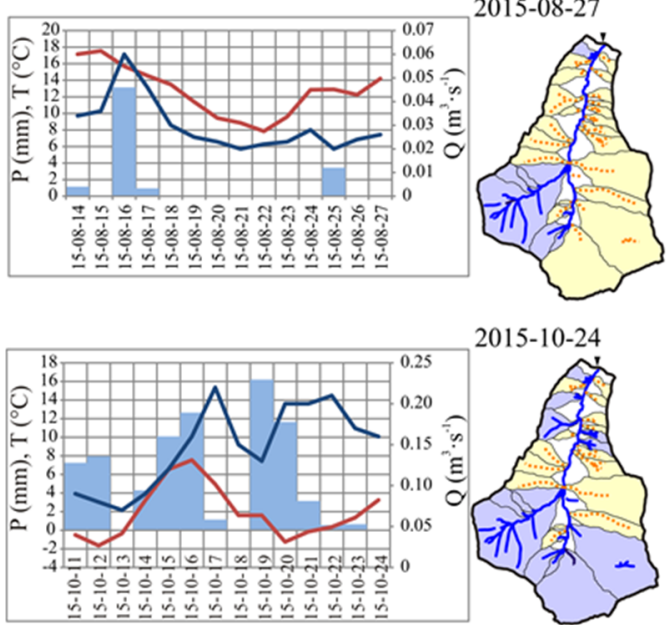

precipitation $[\mathrm{P}]$

$\sim$ temperature $[\mathrm{T}]$

Strążyski Potok discharge [Q]

$\nabla$ water gauge of IMWM

$\widetilde{1}$ water divide to water gauge of IMWM

2 hydrologically active subcatchments

3 hydrologically non-active subcatchments

— perennial streams

Fig. 6 Meteorological situation in the two-week period preceding field observations, and hydrological activity of elementary catchments and rivers in the Strążyski Potok catchment. 
components of their environment (e.g. Dobija and Dynowska 1975; Jencso and McGlynn 2011). The assessment of average permeability in all elementary catchments of the SP catchment is $I_{p}=3.28$, and indicates good conditions of water retention in the rock massif. The highest permeability is characteristic of catchments No. $2\left(I_{p}=3.88\right)$ and No. $7\left(I_{p}=3.78\right)$, covering the north-eastern slopes of Giewont (Figs. 7B, 7-E). Therefore, catchments with the best rock infiltration conditions were ascribed class 1, not guaranteeing discharge permanence in a river channel. The worst filtration conditions were determined for seven catchments in the lower part of the study area (No. 13, 17, 21, 22, 23, 24, 25), for which $I_{p}=1.41-2.96$.
They favour river runoff (the catchments are therefore included in class 4) (Fig. 7-E).

In the mountains, efficient filtration volume is substantially modified by slope inclination. Therefore, considerable potential water retention in the southern, highest located part of the catchment is reduced by its high slope inclination. The average slope of the analysed catchment (until the water gauge) is $34.4^{\circ}$, and this is one of the highest among catchments of streams flowing from the northern slopes of the Tatra Mountains. Average slope inclination of elementary catchments generally decreases from the Giewont massif, where the slopes of two (No. 2 and 7) exceed even $40^{\circ}$ (Figs. 7-A, 7-D), to catchments in the
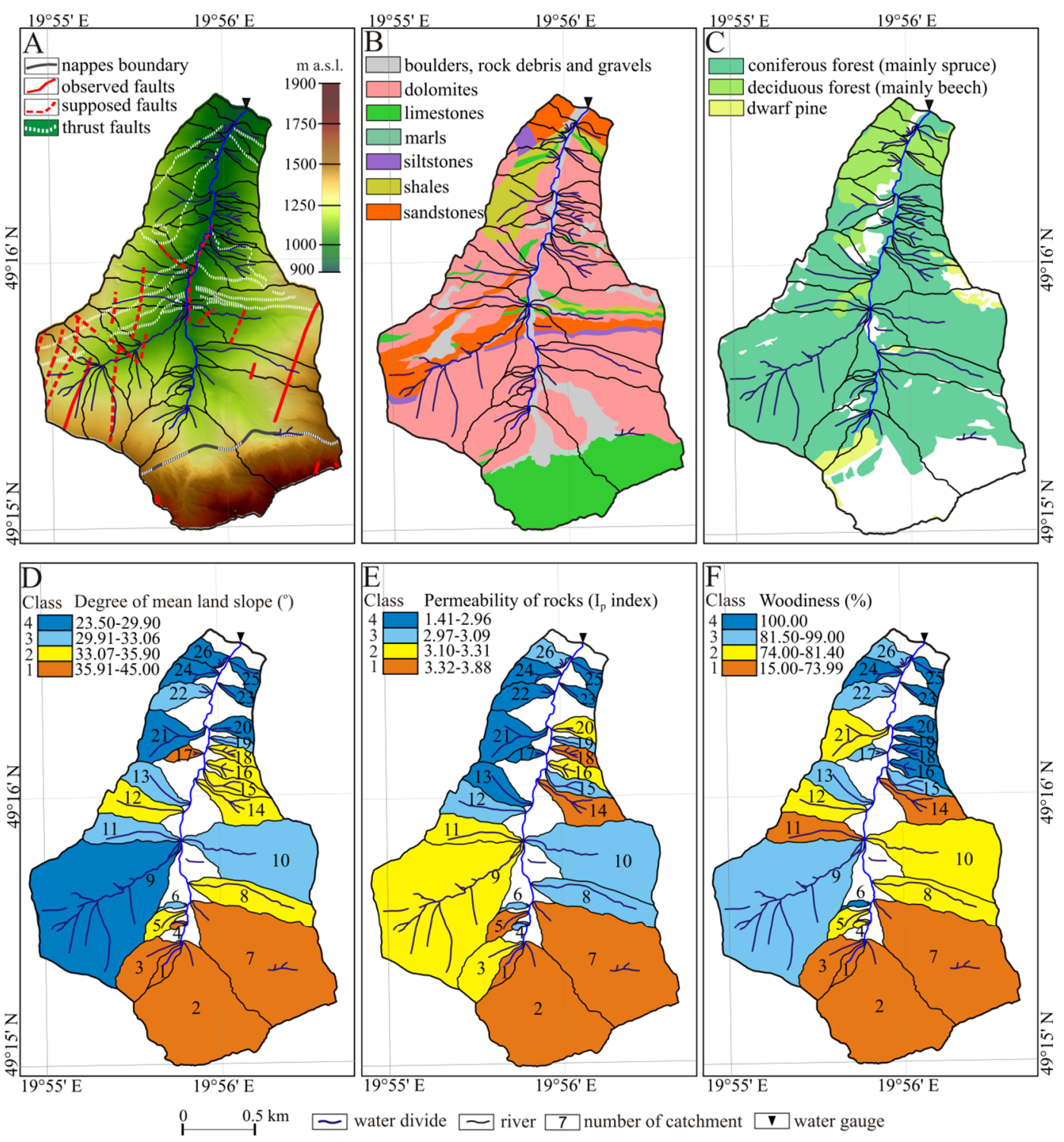

Fig. 7 Analysed non-climatic physiographic elements of the Strązyski Potok catchment determining discharge periodicity: A) relief and tectonics, B) types of rocks, C) forest cover, D) class of average land slope, E) class of rock permeability, F) class of forest cover - forest retention. 
northern, lowest part of the catchment with slopes not exceeding $25^{\circ}$ (catchments No. 25 and 26). In the case of intensive rainfall, the time of water flow from the entire catchment to the water gauge in 2015 took from several to a dozen hours (Fig. 5). Rapid loss of water resources in the catchment causes periodicity of stream discharge.

Land cover plays a considerable role in maintaining mountain river discharge periodicity. In the northern and eastern part of the Giewont massif, two catchments feature much different land cover than the rest of the study area: No. 2 and 7 . Rock screes, debris and mounds occupy more than half of their surface area (Figs. 7A, Fig.-F). Moreover, the area of eight elementary catchments is completely covered with tree and thicket (bush) vegetation, and in three further catchments, the share of these plant communities exceeds $90 \%$.

Catchments No. 1, 2, 3 and 7 are characterised by a large surface of highly permeable rocks and higher than average slope inclination. These elementary catchments also have the smallest share of forest retention areas (Figs. 7-D, 7-E and Fig. 7-F). As a result, non-climatic components of the environment of these elementary catchments do not favour perennial river function and therefore, were classified as class 1. Water in the bed of these streams occurs as a direct response to precipitation, and discharge is short-term. These streams receive little or no water from springs and recharge from melting snow is not long-term.

\subsection{Analysis of climatic conditions}

The analysis of climatic conditions on water abundance shows that the worst conditions occurred in July and August 2015 (Fig. 8). Such a situation was at that time determined by very low precipitation accompanied by high air temperatures. Unfavourable climatic conditions affecting river alimentation were also recorded in the winter period (December, January and February), when low air temperatures occurred in all elementary catchments of the SP catchment. In three observation periods (April, June and October), the recorded conditions were the most favourable for river channels recharge. On 19 April and 24 October 2015, all catchments were included in class 4 with the most favourable climatic conditions.

The spatial analysis of climatic conditions permits designation of four phases of river discharge periodicity in 2015 (Fig. 8):

- winter: period of low temperatures and snowfalls, unfavourable for river functioncatchments in classes 1-2 (December-March);

- spring-summer: supplementation of the water resources of rivers with precipitation waters and meltwaters - catchments in classes 3-4 (April-June);

- summer: impoverishment of water resources in rivers as a result of lack of precipitation and occurrence of high temperatures - catchments in classes 1-2 (July-September);

- autumn: renewal of water resources through atmospheric precipitation at lower temperatures catchments in classes 3-4 (October).

\subsection{Assessment of the degree of correspondence between the environmental potential of catchments and discharge periodicity of streams}

The assessment of the degree of correspondence between the environmental potential and periodicity discharge had a three-stage character (Fig. 9). In the first stage, the environmental potential of climatic and non-climatic elements influencing outflow from individual elementary catchments was assessed separately.

In this study area, climatic factors classification demonstrated the distribution of precipitation and air temperature typical for mountain catchments (Fig 9A). The three catchments (No. 2, 3, 7) located in the highest parts of the SP catchment area are characterized by high precipitation and low air temperature, which guarantees low evaporation. These areas, having therefore very good potential climatic conditions, were classified as 4 th, the highest class. Thus, the streams draining them should carry water continuously. However, significant slopes, high permeability of fractured rocks and negligible forest cover do not allow for prolonged water retention, which is in turn expressed by the low class of nonclimatic factors characterising their environmental potential (Fig 9-B). Continuous discharge in stream channels (Fig. 9-A) is also favoured by climatic conditions typifying the mid-elevation zone (catchments No. 8-14), which were assessed as class 3. The elementary catchments located in the northern, lowest part of the SP catchment are in turn characterised by relatively least favourable climatic conditions. In contrast to worse climatic conditions, the assessment of their non-climatic conditions 


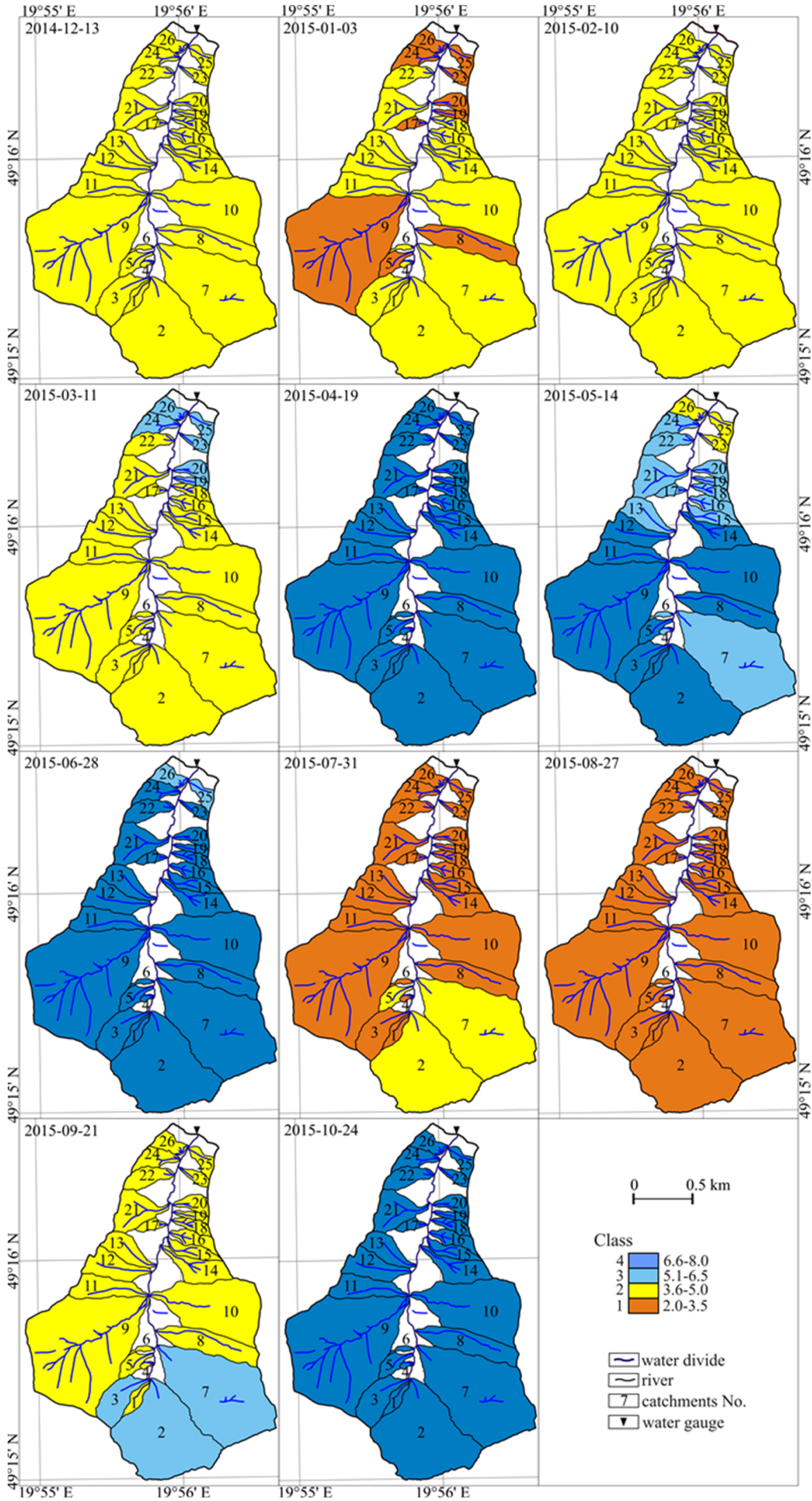

Fig. 8 Classification of climatic conditions permitting the occurrence of water in rivers of the elementary catchments. groups them into classes most favourable for the hydrological activity of streams (Fig. 9-B). The minimal gradients of these catchments and their compact forest cover have a positive effect on water retention. Classes of climatic and non-climatic factors of elementary catchments located in the upper and lower part of the whole SP basin hence present opposing conditions for maintaining discharge periodicity.

The second stage of the analysis, consisting in summing up the classes representing climatic and non-climatic factors, allowed the generation of information on the overall (total) environmental potential of the analysed catchments (Fig. 9-C). Catchments occupying the southern part of the study area and minor catchments in its northern part demonstrated good potential. The best environmental conditions are found in the catchment of Potok Grzybowiecki (No. 9), which combines good climatic and non-climatic features on an equal level. In contrast, the weakest potential for outflow formation was observed in minor elementary catchments (No. 15-19) situated in the central part of the SP basin, and in No. 4, a very minor catchment with poor climatic conditions (class 3) and very poor (class 4) non-climatic conditions.

This assessment classifying catchments according to their 

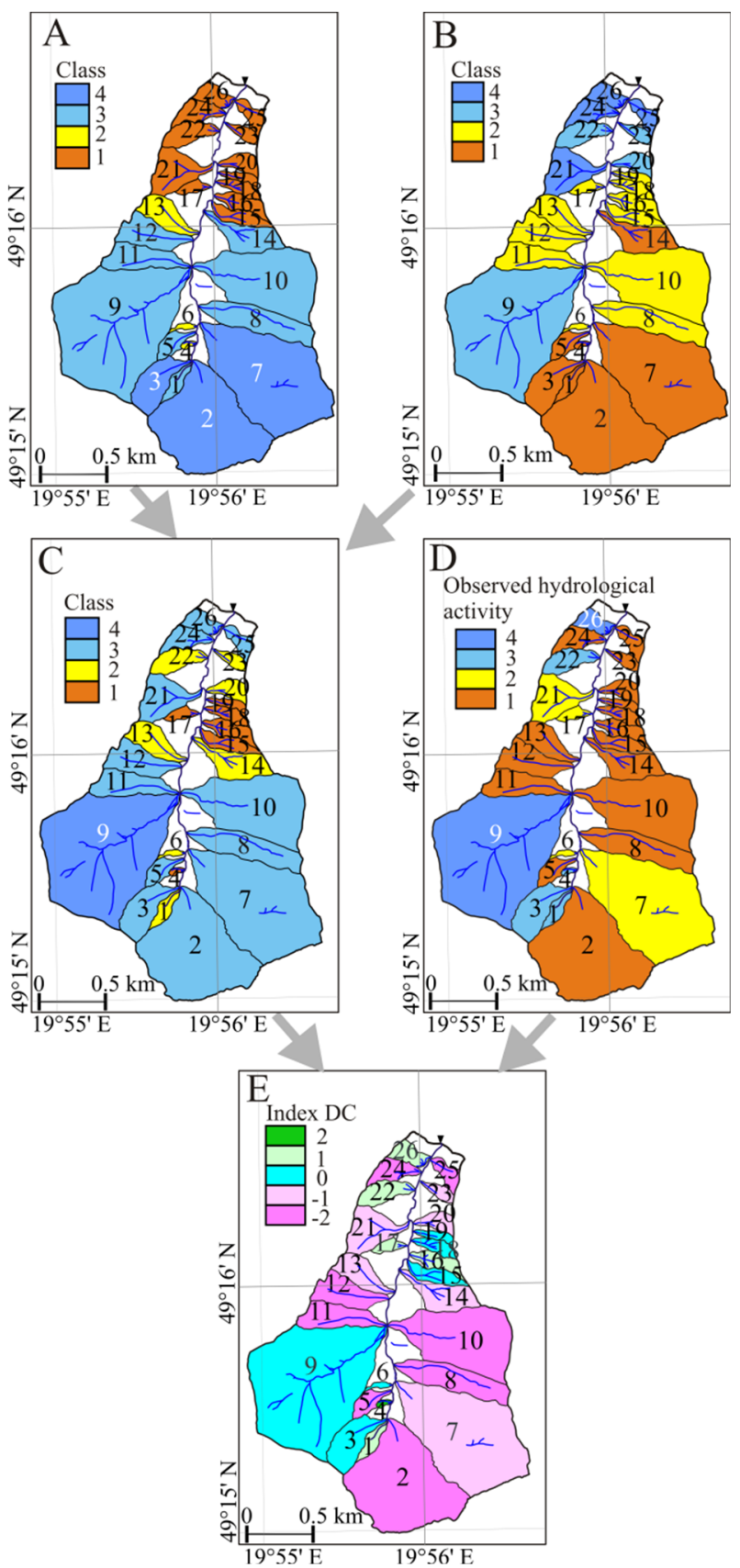

Fig. 9 The assessment of discharge periodicity in SP catchment using selected classified environmental conditions (A - the environmental potential of climatic elements in hydrological year 2015; B - the environmental potential of non-climatic elements; C total potential of climatic and non-climatic elements; D hydrological activity of streams in elementary catchments observed in 2015; E - the degree of agreement (Index DC) of the applied system for assessing the environmental conditions of individual catchments, with field observations).

environmental conditions was related to the actual results of field observations (Fig. 9-D). The frequency of a stream's discharge in its estuarine section was also included into four classes, the significance of which is determined, as in the previously conducted assessments, by the class number (Fig. 9-D). Of the 26 catchments controlled in the 2015 hydrological year, streams can be described as perennial only in 2 of them. These drained catchments No. 9 and 26 (class 4). In the streams of 11 catchments, outflow was observed between 2 and 8 times (classes 1-2). For this reason they can be considered as intermittent streams. In the catchment of stream No. 10, water was observed only once (during the April thaw) and in as many as 12 other catchments, no outflow was recorded. These streams can be called episodic (class 4).

The final stage of the analysis was based on applying the difference of the values of the environmental potential classes of the catchments (Fig. 9-C) with the classes of hydrological activity of their main streams (Fig. 9-D). This made it possible to determine the degree of agreement expressed as Degree Correspondence Index (Index DC= hydrological activity class of catchments' stream environmental potential class of catchment) of the applied system for assessing the environmental conditions of individual catchments, with field observations (Fig. 9-E).

A zero value of the index indicates the correspondence of a specific class of environmental potential with the results of field observations. Positive Index DC values indicate that the streams were more active than the catchment environmental assessment would allow, while negative values indicate weak or no stream activity in 2015 (a year with a high potential of environmental factors). The reason for the discrepancy of the assessments with the field observations may be due to other processes that control water resources that are complex and difficult to identify or describe and are not considered in the proposed system.

\section{Discussion}

A simple and tested method in many catchments for assessing the influence of individual environmental components on the course of hydrological phenomena is the method of landscape hydrological potential (LHP) proposed by Lepeška (2010, 2013), Lepeška et al. (2017) and Wałęga et al. (2020). It was applied, for example, to determine the predictability of maximum flows of selected rivers of southern Poland and Slovakia 
(Wojkowski et al. 2019). Several of the methods included in the above-cited works were employed with some modifications in the assessment and classification of environmental conditions affecting the discharge periodicity in the SP catchment. Unlike the LPH method, all non-climatic and climatic attributes were assumed to be equal, without determining their importance relative to other attributes. The values of each attribute were divided into four classes. The division into classes were quartiles dividing the community into four parts in terms of abundance. The quartiles are convenient parameters for analysing the structure of the data and for determining the value of the characteristic around which the collected data are grouped. Evaluation of the degree of influence of selected climatic and non-climatic elements of the catchment on the discharge periodicity of streams confirmed the latitudinal zonation of environmental quality expressed in four classes.

Classification of climatic factors (precipitation and temperature) was carried out on the basis of data from two meteorological stations that were located at extreme altitudes. Between them, there is no measurement site (point) in the SP catchment area. The applied hypsometric interpolation method enabled determination of precipitation and mean air temperature for two-week periods preceding streamflow observations in each catchment. The adoption of two-week periods to evaluate the effect of climatic conditions on stream water quality resulted from the dynamics of hydrometeorological processes manifested by short-term outflow-to-outflow reactions. A similar period (15 days) was adopted by Radczuk (2008) in developing a model of hydrological processes for the Odra river basin (western Poland). The classified values of air temperature and precipitation were summed up into the group of climatic factors.

In the case of the evaluation of elementary catchments forming the SP basin that is built of highly fractured and karstic solid rocks, determining the degree of permeability was a difficult task. The evaluation of this feature was, therefore, performed in two stages, having at disposal the results of permeability studies of the Tatra massif (Barczyk et. al 1995, 2002). The best permeability was found in elementary catchments of the upper part of the SP basin that were built of fractured limestone and dolomite, and largely covered with loose rock rubble. Such conditions are not conducive to long persistence of water in stream channels, and therefore these catchments are classified as class I. The assessment of rock permeability of the catchment, however, did not take into account the degree of dissection of the massifs by tectonic faults (which are usually good groundwater circulation routes). As was stated in the study from 1960 (Wit, Ziemońska), in the middle part of its catchment, the SP river is fed by numerous riverbed springs. Indeed, ln the Grzybowiecki Potok river (catchment No. 9), originating from karst springs, outflow was observed 10 times during eleven field surveys. The good water quality of the Grzybowiecki Potok is also a result of numerous springs feeding the valley bottom at the contact between dolomites and shales. According to the 1950 s data, below the mouth of the Grzybowiecki Potok, the SP received water only from one perennial left tributary. This was the Potok pod Samkowa Czuby river (catchment No. 26), which originated from a spring that also flowed at the contact between the dolomites and shales (Wit and Ziemońska 1960). In 2015, Potok Samkowa Czuby river (No. 26) appeared to be the only perennial stream in the SP basin. Springs generally accompany tectonic zones. Since the majority of tectonic zones are suppressed faults and information on the occurrence of springs is of a similar nature as the discharge periodicity marked on maps, i.e. being the result of short-term observations, they were not taken into account in the development of our proposed environmental assessment system. The issue of introducing information on the occurrence and outflow of springs is undoubtedly fundamental when studying the discharge periodicity of mountain streams. However, the registration of outflows hidden in the channel is practically impossible during one-day patrol surveys.

The comparison of three classifications of terrestrial environment elements: catchment slope, permeability and forest cover showed that a considerable part of the whole SP basin is characterized by poor and very poor conditions for keeping water in its stream beds. Elementary catchments of this nature occupy $63 \%$ of the study area, and in most of the catchments with good conditions, the watercourses functioned with varying degrees of discharge periodicity.

The catchments of the streams in the beds of which water flow was recorded constantly or almost constantly, were, according to the observations made in 2015, situated in different parts of the SP catchment, and were characterised by being of 
different sizes. For example, catchment No. 9 is located in the upper part of the SP catchment. Grzybowiecki Potok river, which flows out of it, has water almost constantly. This catchment is characterised by having one of the largest area of elementary catchments. In contrast, catchment No. 26, which is small in area and located in the lower part of the SP catchment, also had reported outflow throughout the year. Two sub-basins (No. 2 and 5) located in the southern, steepest part of the SP catchment furnish further evidence for the lack of relationship between catchment size and discharge periodicity. Catchment No. 2 is over 19 times larger than catchment No. 5 and no outflow was observed in both of them in 2015.

Combining the classes of climatic parameters of catchments with those of non-climatic parameters was used to determine the degree of correspondence between the assessed conditions and the actual discharge periodicity of streams recorded during the field studies. Despite the fact that full compliance was found (Index DC = o) only in seven catchments), it is also worth noticing those areas where, despite good environmental conditions, their contained streams did not run water at all (Index DC = -1, -2), and those whose environmental potential enabled flow into their stream beds, but such situation was not recorded during field observations (Index DC $=+1,+2$ ). Explanations for these inconsistencies can be found in the classification generation procedures or by the lack of frequency of observations. The most advantageous solution to this problem would be to conduct continuous observations on a few selected streams with diverse environments that were initially assessed by the methods proposed in this paper. By determining the discharge periodicity of each stream in an annual cycle, it would be possible to recalibrate the system for assessing environmental values that favour or disfavour the discharge periodicity of streams.

Modern methods of tracking and annotating outflow in small and unsurveyed mountain streams still face obstacles due to the inaccessibility of the terrain and the inability to apply remote sensing techniques. This obstacle also concerns the recording of streams flowing through dense forests. The procedure presented in this paper leads to the elucidation of the causes of the periodicity of streams, and complements previous research results concerning the mountain areas of the temperate climate zone.

\section{Conclusion}

This paper analyses the discharge periodicity of mountain streams over the cycle of one hydrological year. In particular, it focused on how non-climatic factors and climatic conditions affecting the catchment, in turn, affect the discharge periodicity. The results of the classification of these factors were related to field observations. The analyses made it possible to present the following main conclusions:

(1) A simple-to-apply method for assessing the influence of individual environmental components on discharge periodicity provides a basis for developing a conceptual, more developed hydrological model;

(2) This method should be applied before undertaking field observations because it indicates areas with high probability (potential) of occurrence of periods of water disappearance in river channels;

(3) Validation of the method can be done by conducting frequent field observations, and the results should be used to explain any inconsistencies in the applied assessment on comparison with the recorded phenomena,

(4) In karst areas, streams draining elementary catchments are characterized by discharge periodicity, along with simultaneous constant discharge into the main river - in this case - the Strążyski Potok;

(5) In regional and supraregional perspectives, the study of discharge periodicity of mountain streams and the relatively simple physical and hydrological structure of mountain catchments located in protected areas facilitate verification of hypotheses on the trends in water resource change.

\section{Acknowledgements}

The authors would like to thank the management of the Tatra National Park for permission to conduct field research. The authors are also grateful to the anonymous reviewers and the editor of this journal for their detailed comments and suggestions that greatly improved the quality of the manuscript.

\section{Open Access}

This article is licensed under a Creative Commons Attribution 4.0 International License, which permits use, sharing, adaptation, distribution 
and reproduction in any medium or format, as long as you give appropriate credit to the original author(s) and the source, provide a link to the Creative Commons license, and indicate if changes were made. The images or other third party material in this article are included in the article's Creative Commons license, unless indicated otherwise in a credit line to the

\section{References}

Bac-Moszaszwili M, Burchart M, Głazek J, et al. (1979) Geological map of the Polish Tatras 1:30 ooo. Wyd Geol, Warszawa. (In Polish)

Ballesteros-Cánovas JA, Czajka B, Janecka K, et al. (2015) Flash floods in the Tatra Mountain streams: frequency and triggers. Sci Total Environ 511: 639-648. https://doi.org/10.1016/j.scitotenv.2014.12.081

Barczyk G, Humnicki W, Małecka D (1995) Determination of hydraulic conductivity coefficient of the Tatra massif on the base of fissurity measurements. Współczesne problemy hydrogeologii 7: 231-238. (In Polish)

Barczyk G, Humnicki W, Żurawska G (2002) Dependence of the karstic waters in the Tatra Mts. on changing atmospheric conditions. Acta Geol Pol 52(1): 117-127.

Broxton PD, Troch PA, Lyon SW (2009) On the role of aspect to quantify water transit times in small mountainous catchments. Water Resour Res 45(8): Wo8427. https://doi.org/10.1029/2008WRoo7438

cbdgportal.pgi.gov.pl/smgt/ (Accessed on 10 April 2020)

Chorley RJ, Dale PF (1972) Cartographic problems in stream channel delineation. Cartography 7(4): 150-162. https://doi.org/10.1080/00690805.1972.10437698

Colson T, Gregory J, Dorney J, et al. (2008) Topographic and soil maps do not accurately depict headwater stream networks. Natl wetlands newsl 30(3): 25-28.

Costache R, Hong H, Pham QB (2020) Comparative assessment of the flash-flood potential within small mountain catchments using bivariate statistics and their novel hybrid integration with machine learning models. Sci Total Environ 711: 134514. https://doi.org/10.1016/j.scitotenv.2019.134514

Costigan KH, Jaeger KL, Goss CW, et al. (2016) Understanding controls on flow permanence in intermittent rivers to aid ecological research: Integrating meteorology, geology and land cover. Ecohydrology 9(7): 1141-1153. https://doi.org/10.1002/eco.1712

Datry T, Larned ST, Tockner K (2014) Intermittent rivers: A Challenge for Freshwater Ecology. BioScience 64 (3): 229-235. https://doi.org/10.1093/biosci/bito27

Dobija A, Dynowska I (1975) The importance of physiographic parameters for determining of the river outflow magnitude. Folia Geogr Ser Geogr-Phys 9: 77-129. (In Polish)

Dorney J, Russell P (2018) North Carolina Division of water quality methodology for identification of intermittent and perennial streams and their origins. In: Wetland and Stream Rapid Assessments. https://doi.org/10.1016/B978-0-12-805091-0.00014-1

Fritz KM, Hagenbuch E, D'Amico E, et al. (2013) Comparing the extent and permanence of headwater streams from two field surveys to values from hydrographic databases and maps. J Am Water Resour Assoc 49(4): 867-882 https://doi.org/10.1111/jawr.12040

Gan R, Sun L, Luo Y (2015) Baseflow characteristics in alpine rivers-a multi-catchment analysis in Northwest China. J Mt Sci 12(3): 614-625. https://doi.org/10.1007/s11629-013-2959-z

Górnik M, Holko L, Pociask-Karteczka J, et al. (2017) Variability of precipitation and runoff in the entire High Tatra Mountains in the period 1961-2010. Pr Geogr 151: 53-74. material. If material is not included in the article's Creative Commons license and your intended use is not permitted by statutory regulation or exceeds the permitted use, you will need to obtain permission directly from the copyright holder. To view a copy of this license, visit

http://creativecommons.org/licenses/by/4.o/.
https://doi.org/10.4467/20833113PG.17.022.8034

Guastini E, Zuecco G, Errico A, et al. (2019) How does streamflow response vary with spatial scale? Analysis of controls in three nested Alpine catchments. J Hydrol 570: $705-718$.

https://doi.org/10.1016/j.jhydrol.2019.01.022

Hess MT (1996) Climate. In: Mirek Z (ed.), The nature of the Tatra National Park. Wyd. TPN. Kraków-Zakopane (In Polish)

Holko L, Hlavatá H, Kostka Z, et al. (2009) Hydrological regimes of small catchments in the High Tatra Mountains before and after extraordinary wind-induced deforestation. Folia Geogr Ser Geogr-Phys 40: 33-44.

Jencso KG, McGlynn BL (2011) Hierarchical controls on runoff generation: Topographically driven hydrologic connectivity, geology, and vegetation. Water Resour Res 47(11): 431-435. https://doi.org/10.1029/2011WR010666

Jensen CK, McGuire KJ, Shao Y, et al. (2018) Modelling wet headwater stream networks across multiple flow conditions in the Appalachian Highlands. Earth Surf Process Landf 43(13): 2762-2778.

https://doi.org/10.1002/esp.4431.

Karabová B, Sikorska AE, Banasik K, et al. (2012) Parameters determination of a conceptual rainfall-runoff model for a small catchment in Carpathians. Ann Warsaw Univ of Life Sci - SGGW, Land Reclam 44(2): 1-8.

https://doi.org/ 10.2478/v10060-011-0071-z

Klimaszewski M (1988) Relief of the Polish Tatras. Wyd. PWN, Warszawa. (In Polish)

Langford E (2006) Quartiles in elementary statistics. J Stat Educ 14(3): 1-6.

https://doi.org/10.1080/10691898.2006.11910589

Latron J, Lana-Renault N (2018) The relevance of hydrological research in small catchments-A perspective from long-term monitoring sites in Europe. Cuad Investig Geogr 44(2): 387395 .

http://doi.org/10.18172/cig.3499

Lepeška T (2010) Hydric potential of landscape and integrated river basin management in mountain and submontane regions. Ecohydrol Hydrobiol 10(1): 13-24. https://doi.org/10.2478/v10104-010-0017-9

Lepeška T (2013) Hydric potential of selected river basins in Slovakia. Ecohydrol Hydrobiol 13(3): 201-209. https://doi.org/10.1016/j.ecohyd.2013.08.004

Lepeška T, Radecki-Pawlik A, Wojkowski J, et al. (2017) Hydric potential of the river basin: Prądnik, Polish Highlands. Acta Geophys 65: 1253-1267.

https://doi.org/10.1007/s11600-017-0093-y

Li HY, Wang YX, Jia LN, et al. (2014) Runoff characteristics of the Nen River Basin and its cause. J Mt Sci 11(1): 110-118. https://doi.org 10.1007/s11629-012-2332-7

Liiv I (2010) Seriation and matrix reordering methods: An historical overview. Stat Anal Data Min 3(2): 70-91. https://doi.org/10.1002/sam.10071

Łajczak A (1996) Hydrology. In: Mirek Z (ed.), The nature of the Tatra National Park. Wyd. TNP, Kraków-Zakopane. (In Polish) Madzia M, Suchanek E, Więzik B (2013) Assess variability of runoff in a small mountainous catchments. Inżynieria Ekologiczna 32: 122-130. (In Polish) 
Topographic Map of Polish Tatra Mountains, M-34-10o-B-b-3. Nazwa: Kościelisko. 1995; godło: M-34-100-B-b-4. Nazwa: Zakopane-Płd, 1995. Avaiable online at:

https://mapy.geoportal.gov.pl (Accessed on 22 April 2020)

Martin C, Kampf SK, Hammond JC, et al. (2021) Controls on streamflow densities in semiarid rocky mountain catchments. Water 13(4): 521.

https://doi.org/10.339o/w13040521

Niedźwiedź T, Łupikasza E, Pińskwar I, et al. (2015) Variability of high rainfalls and related synoptic situations causing heavy floods at the northern foothills of the Tatra Mountains. Theor Appl Climatol 119 (1-2): 273-284.

https://doi.org/10.1007/s00704-014-1108-0

Paillex A, Siebers AR, Ebi C, et al. (2020) High stream intermittency in an alpine fluvial network: Val Roseg, Switzerland. Limnol Oceanogr 65(3): 557-568.

https://doi.org/10.1002/lno.11324

Penna D, van Meerveld HJ, Oliviero O, et al. (2015) Seasonal changes in runoff generation in a small forested mountain catchment. Hydrol Process 29(8): 2027-2042. https://doi.org/10.1002/hyp.10347

Peña-Gallardo M, Vicente-Serrano SM, Hannaford $\mathrm{J}$, et al. (2019) Complex influences of meteorological drought timescales on hydrological droughts in natural basins of the contiguous Unites States. J Hydrol 568: 611-625. https://doi.org/10.1016/j.jhydrol.2018.11.026

Peters NE, Freer J, Beven K (2003) Modelling hydrologic responses in a small forested catchment (Panola Mountain. Georgia. USA): a comparison of the original and a new dynamic TOPMODEL. Hydrol Process 17(2): 345-362. https://doi.org/10.1002/hyp.1128

Pociask-Karteczka J, Baścik M, Nieckarz Z (2010) Space-time variability of river runoff in the Tatra Mountains. In: Kotarba A (ed.), Nature of the Tatra National Park and Man. Tom I, Tatrzański Park Narodowy, Zakopane (In Polish)

Post DA, Jakeman AJ (1996) Relationships between catchment attributes and hydrological response characteristics in small Australian mountain ash catchments. Hydrol Process 10(6): 877-892.

https://doi.org/10.1002/(SICI)1099-1085(199606)10:6<877: AID-HYP377>3.0.CO;2-T

Radczuk L (2008) Modeling of hydrological processes in the upper and middle Odra river basin. Współczesne Problemy Inżynierii Środowiska, Monograph (57)VII: 1-118. Available online at:

https://www.dbc.wroc.pl/Content/18744/PDF/o8_Modelow anie\%2oprocesow\%2ohydro_Radczuk\%20L.pdf (Accessed on 23 May 2020) (In Polish)

Radecki-Pawlik A, Wałęga A, Młyński D, et al. (2020) Seasonality of mean flows as a potential tool for the assessment of ecological processes: Mountain rivers, Polish Carpathians. Sci Total Environ 716: 136988. https://doi.org/10.1016/j.scitotenv.2020.136988

Ragettli S, Zhou J, Wang H, et al. (2017) Modeling flash floods in ungauged mountain catchments of China: A decision tree learning approach for parameter regionalization. J Hydrol 555: 330-346. https://doi.org/10.1016/j.jhydrol.2017.10.031

Robinson CT, Tonolla D, Imhof B, et al. (2016) Flow intermittency, physico-chemistry and function of headwater streams in an Alpine glacial catchment. Aquat Sci 78(2): 327341.

https://doi.org/10.1007/s00027-015-0434-3

Robredo Sánchez JC, Rojo Núñez I, Mintegui Aguirre JÁ (2012) An approximate method for estimating monthly mean flows in small mountain watersheds. Ecología 24: 27-42.

Rutkowska A, Kohnová S, Banasik K, et al. (2018) Flow characteristics of intermittent rivers in Slovakia. Ann Warsaw Univ of Life Sci - SGGW, Land Reclam 5O(3): 215-227. https://doi.org/10.2478/sggw-2018-0017

Sando R, Blasch KW (2015) Predicting alpine headwater stream intermittency: A case study in the northern Rocky Mountains. Ecohydrol Hydrobiol 15(2): 68-80.

https://doi.org/10.1016/j.ecohyd.2015.04.002

Shanafield M, Bourke SA, Zimmer MA, et al. (2021) An overview of the hydrology of non - perennial rivers and streams. Wiley Interdisciplinary Reviews: Water 8(2): e1504.

https://doi.org/10.1002/wat2.1504

Shen X, Zhang S, Shen Q, et al. (2020) Multivariate similarity clustering analysis: a new method regarding biogeography and its application in global insects. Integr Zool.

https://doi.org/10.1111/1749-4877.12485

Spinoni J, Naumann G, Vogt JV, et al. (2015) The biggest drought events in Europe from 1950 to 2012. J Hydrol: Regional Studies 3: 509-524.

https://doi.org/10.1016/j.ejrh.2015.01.001

Tatra mountains (Polish part): photogrammetric map 1:20 ooo. 1938. Military Geographical Institute, Warsaw. (Accessed on 30 May 2020)

Tukey JW (1977) Exploratory data analysis, Addison-Wesley Series in Behavioral Science: Quantitative Methods 2: 131-160. Downloaded from:

http://theta.edu.pl/wp-

content/uploads/2012/10/exploratorydataanalysis_tukey.pdf (Accessed on 30 July 2021)

Villines JA, Agouridis CT, Warner RC, et al. (2015) Using GIS to delineate headwater stream origins in the Appalachian coalfields of Kentucky. J Am Water Resour Assoc 51(6): 16671687.

Wałęa A, Młyński D, Wojkowski J, et al. (2020) New empirical model using landscape hydric potential method to estimate median peak discharges in mountain ungauged catchments. Water 12(4): 983.

https://doi.org/10.3390/w12040983

Williamson TN, Agouridis CT, Barton CD, et al. (2015) Classification of ephemeral, intermittent, and perennial stream reaches using a TOPMODEL based approach. J Am Water Resour Assoc 51(6): 1739-1759. https://doi.org/10.1111/1752-1688.12352

Wit K, Ziemońska Z (1960) Hydrography of the Western Tatras: explanations to the hydrographic map of the Western Tatras 1: 50 ooo. Dokumentacja Geograficzna, PAN, Instytut Geografii. (In Polish)

Wojkowski J, Młyński D, Lepeška T, et al. (2019) Link between hydric potential and predictability of maximum flow for selected catchments in Western Carpathians. Sci Total Environ 683: 293-307. https://doi.org/10.1016/j.scitotenv.2019.05.159

Woźniak A (2013) Precipitation in 2010 in the Polish Carpathians against the background of 1881-2010. Pr Geogr 133: 35-48. (In Polish)

Zadeh LA (1996) Fuzzy sets. In: Klir JK and Yuan B (eds.) Fuzzy sets, fuzzy logic, and fuzzy systems: selected papers by Lotfi A Zadeh. Binghamton University-SUNY, Binghamton, New York.

https://doi.org/10.1142/9789814261302_0021

Zal N, Bastrup-Birk A, Bariamis G, et al. (2015) Water-retention potential of Europe's forests. A European overview to support natural water-retention measures, EEA Technical report No 13.

Zuecco G, Penna D, Borga M (2018) Runoff generation in mountain catchments: long-term hydrological monitoring in the Rio Vauz Catchment, Italy. Cuad de Investig Geogr 44: 397-428. https://doi.org/10.18172/cig.3327

Żelazny M (2012) Spatial-temporal variability of physicochemical characteristics of waters of the Tatra National Park. IGiGP UJ, Kraków. (In Polish)

Żelazny M, Wolanin A, Pęksa $€$ (2013) The abundance of water ecosystems in the area of the Tatra National Park. Lasy Państwowe, Kraków. (In Polish) 